\title{
KEDUDUKAN KUASA MENJUAL ATAS DASAR SURAT KETERANGAN NOTARIS TENTANG PEMBAYARAN LUNAS DALAM PEMBUATAN AKTA JUAL BELI BALIK NAMA
}

\author{
Sumardi \\ Magister Kenotariatan Universitas Udayana
}

\author{
ABSTRACT \\ THE EXISTENCE OF SELL ATTORNEY BASED ON NOTARY STATEMENT LETTER \\ ABOUT KEEL PAYMENT IN MAKING SALE-BUY'S NAME RETURN
}

Agreement Cordage Deed of Sale-Buy and Sell Attorney basically represent evidence appliance showing tied of the parties in an agreement about goods and price / object as sales contract. Meanwhile by normatif, problem to existence of sell attorney which was utilized in registration of land right switchover did not be arrangement in Government Regulation No. 24 Year 1997 about Land Registry. The blankness of the Norm had caused the happening of solving of registration of land right switchover which different each other between PPAT according to knowledge had and its bravery strive invention of law. Based of the situation, hence problem of this research is how to exsitance Notary letter statement which is power with sell as base making of sale act buy to return the name of made by and/or before PPAT and do attorney Sell following Notary letter statement can be conceived as an absolute power and sale-buy to name return can be made by appliance to registration of land right switchover at Land Office.

Based on the blankness of norm in the Government Regulation No. 24 Year 1997 for the existence of Agreement Cordage Deed of Sale-Buy and Sell Attorney, hence this research was be classified into normative legal research with appproached by conceptual and statute appproach. The legal materials of this research were based on primary, secondary and tertiary legal materials. The legal materials was be descripted henceforth to be interpreted, systematization, analysed, evaluated and also given argument to get conclusion of the problems.

Result of the research indicate that dimiciling Notary statement letter with attorney sell was as aid agreement and act underhand as a mean to protect buyer position as well as to help the Notary/PPAT work in making sale-buy act along with registration of land right switchover becoming sales object. Meanwhile, have the sell attorney following Notary statement letter non as absolute attorney, but as a help deed from antecedent agreement (aid agreement) functioning and have a purpose to draw up, to affirming, strengthening, arranging, altering or finishing its sales contractual terms before notary/PPAT come up with registration of land right switchover becoming sales object.

Key words : Exsistence, Attorney sell, Deed, Notary, statement letter, keel.

\section{PENDAHULUAN}

\subsection{Latar Belakang Masalah}

Tujuan pendaftaran tanah dapat dijumpai pada ketentuan Pasal 3 PP No. 24 Tahun 1997 yang menentukan dengan tujuan sebagai berikut :

Untuk memberikan kepastian hukum dan perlindungan hukum kepada pemegang hak atas suatu bidang tanah, satuan rumah susun, dan hak-hak lain yang terdaftar agar dengan mudah dapat membuktikan dirinya sebagai pemegang hak yang bersangkutan; untuk menyediakan informasi kepada pihak-pihak yang berkepentingan termasuk pemerintah agar dengan mudah dapat memperoleh data yang diperlukan dalam mengadakan perbuatan hukum mengenai bidang-bidang tanah dan satuan-satuan rumah susun yang sudah terdaftar; dan untuk terselenggaranya tertib administrasi pertanahan.

$$
\text { Tiap-tiap tanah yang telah }
$$

didaftarkan akan diberikan nomor hak serta mempunyai fungsi sebagai bukti autentik dengan bentuk tertulis yang dituangkan kedalam sertipikat hak. Oleh karena itu, secara yuridis, negara 
mengakui kepemilikan atas suatu tanah terhadap subjek hak atas tanah yang namanya terdaftar dalam sertifikat tanah tersebut dan dengan demikian, maka pihak lain tidak dapat mengganggu gugat kepemilikan tanah tersebut.

Mengenai proses pendaftaran peralihan hak-hak atas tanah diatur lebih lanjut pada Pasal 37 ayat (1) PP No. 24 Tahun 1997 yang menetapkan :

Peralihan hak atas tanah dan hak milik atas satuan rumah susun melalui jual beli, tukar menukar, hibah, pemasukan dalam perusahaan dan perbuatan hukum pemindahan hak lainnya, kecuali pemindahan hak melalui lelang, hanya dapat didaftarkan jika dibuktikan dengan akta yang dibuat oleh PPAT yang berwenang menurut ketentuan peraturan perundang-undangan yang berlaku.

Ketentuan tersebut menunjukkan bahwa salah satu perbuatan hukum yang menyebabkan terjadinya peralihan hak atas tanah dan harus didaftarkan balik namanya adalah perbuatan hukum jual-beli yang aktanya dibuat dalam bentuk Akta Jual-Beli (AJB) yang dibuat oleh dan/atau dihadapan Pejabat Pembuat Akta Tanah (PPAT) yang lazimnya disebut dengan AJB balik nama dan selanjutnya digunakan sebagai alat pendaftaran peralihan hak atas tanah.

AJB balik nama juga dapat dibuat dengan berdasar pada akta Perjanjian Pengikatan Jual Beli (PPJB) dan Kuasa Menjual dalam bentuk akta otentik yang dibuat oleh Notaris. Akta-akta tersebut dibuat antara para pihak, di satu pihak sebagai pemilik tanah selaku penjual dan di pihak lain sebagai pembeli dari tanah, di hadapan Notaris sehingga lazim disebut dengan akta notariil. Dalam praktek, pemberian kedudukan Kuasa Menjual seperti di atas telah menyebabkan Kuasa Menjual dijadikan dasar pada proses dibuatnya AJB balik nama dan sekaligus dijadikan alat pendaftaran peralihan hak atas tanahnya pada Kantor Pertanahan di tempat tanah tersebut berada. Sementara itu, Kuasa Menjual tersebut dilengkapi Surat Keterangan dari Notaris yang menerangkan bahwa akta Kuasa Menjual dimaksud bukanlah kuasa mutlak yang dilarang oleh undangundang atau bahwa terhadap tanah dan bangunan sebagai obyek dalam akta Kuasa Menjual tersebut telah terbayar lunas.

Secara normatif, keberadaan kuasa menjual dalam pendaftaran peralihan hak atas tanah tidak dijumpai pengaturannya dalam PP No. 24 Tahun 1997 tentang Pendaftaran Tanah. Kekosongan norma tersebut telah menyebabkan terjadinya penyelesaian pendaftaran peralihan hak atas tanah yang berbeda-beda antar PPAT sesuai pengetahuan yang dimiliki dan keberaniannya melakukan upaya penemuan hukum. Untuk itu, penelitian tentang keberadaan surat keterangan Notaris serta apa akibat hukum yang dapat ditimbulkan bagi Akta Kuasa Menjual berikut kendalakendala dalam permohonan peralihan hak atas tanahnya menjadi menarik dan aktual untuk dikaji.

\subsection{Rumusan Masalah}

Berdasarkan uraian latar belakang masalah tersebut di atas maka dapat dirumuskan permasalahan sebagai berikut : 
1. Bagaimanakah kedudukan surat keterangan Notaris yang dikuti kuasa menjual sebagai dasar dibuatnya akta jual beli balik nama yang dibuat oleh dan/atau dihadapan PPAT ?

2. Apakah akta Kuasa Menjual yang mengikuti surat keterangan Notaris dapat disebut sebagai kuasa mutlak dan akta jual beli balik namanya dapat dijadikan alat pendaftaran peralihan hak atas tanahnya pada Kantor Pertanahan?

\subsection{Tujuan Penelitian}

Secara umum penelitian ini bertujuan mengembangkan Hukum Kenotariatan, Hukum Pertanahan, serta Hukum Perjanjian. Sementara itu, secara khusus mengenai tujuan penelitian ini adalah :

a. Untuk mengetahui dan menganalisis kedudukan surat keterangan Notaris yang diikuti akta Kuasa Menjual sebagai dasar dalam dibuat akta jual beli balik nama yang dibuat oleh dan/dihadapan PPAT.

b. Untuk mengetahui dan menganalisis kedudukan akta Kuasa Menjual yang mengikuti surat keterangan Notaris beserta keberadaan akta jual beli balik nama yang dibuat berdasarkan pada akta Kuasa Menjual yang mengikuti surat keterangan Notaris dikaitkan dengan pendaftaran peralihan hak atas tanah.

\subsection{Manfaat Penelitian}

Secara teoritis, hasil penelitian ini diharapkan untuk pengembangan Ilmu Hukum berkaitan dengan Hukum Kenotariatan, Hukum Pertanahan, serta
Hukum Perjanjian. Selanjutnya secara praktis, hasil penelitian ini diharapkan dapat dipakai oleh Notaris/PPAT dalam pelaksanaan tugas dengan wewenang jabatannya membuat akta otentik khususnya akta Kuasa Menjual tanpa mengikuti akta PPJB dan/atau AJB balik nama. Sementara itu bagi masyarakat, hasil penelitian ini diharapkan dapat memberikan pengetahuan dalam melakukan transaksi jual beli beserta pendaftaran hak atas tanah dan/atau bangunan yang ada di atasnya. Masyarakat nantinya dengan hasil penelitian ini diharapkan dapat mengetahui akta-akta yang benar dan sah dibuat di hadapan Notaris/PPAT dalam kaitannya dengan proses peralihan hak milik atas tanahnya.

\subsection{Kerangka Teoritis}

Dalam menganalisa permasalahan dalam penelitian ini digunakan beberapa teori terkait, yakni Teori Negara Hukum, Asas-Asas Hukum dalam Perjanjian, Teori Perjanjian, dan Teori Kepastian Hukum. Adapun asasasas dan teori-teori hukum tersebut adalah sebagai berikut :

a). Teori Negara Hukum

Istilah negara hukum oleh Philipus $\mathrm{M}$. Hadjon sering disamakan dengan konsep rechtsstaat sehingga negara hukum dipandang sebagai terjemahan dari rechtsstaat. ${ }^{1}$ Hal ini sesuai dengan pandangan Azhary yang berpendapat bahwa negara hukum dapat disamakan dengan rechtstaat ataupun rule of

${ }^{1}$ Philipus M. Hadjon, 2007, Perlindungan Hukum Bagi Rakyat di Indonesia, Sebuah Studi tentang Prinsip-prinsipnya, Penanganannya oleh Pengadilan dalam Lingkungan Peradilan Umum dan Pembentukan Peradilan Administrasi, Peradaban, Surabaya, (selanjutnya disingkat dengan Philipus M. Hadjon I), hal. 66. 
law, mengingat kedua istilah tersebut mempunyai arah yang sama yaitu mencegah kekuasaan absolut demi pengakuan dan perlindungan hak azasi. ${ }^{2}$ Sudargo Gautama selanjutnya berpendapat tentang negara hukum sebagai "negara yang seluruh aksinya didasarkan dan diatur oleh Undang-Undang yang telah ditetapkan semula dengan bantuan dari badan pemberi suara rakyat". ${ }^{3}$ Selanjutnya menurut O. Notohamidjojo, negara hukum diartikan dengan "negara dimana pemerintah dan semua pejabat-pejabat hukum mulai dari Presiden, hakim, jaksa, anggota-anggota legislatif, semuanya dalam menjalankan tugasnya di dalam dan di luar jam kantornya taat kepada hukum". 4 Dengan demikian, adanya unsur asas legalitas dalam unsur rechtsstaat mengamanatkan agar setiap tindakan pemerintah harus berdasar atas hukum. Dengan kata lain, asas legalitas menjadi hal yang penting dalam penyelenggaraan tindakan pemerintahan termasuk yang dilakukan oleh Pejabat Pembuat Akta Tanah maupun Notaris dalam peralihan dan/atau membantu pendaftaran hak atas tanah agar tidak melanggar hak asasi manusia dan/atau tidak menyebabkan seseorang atau sekelompok orang tidak mendapat perlindungan hukum.

b). Asas-asas dalam Hukum Perjanjian

Dalam KUH Perdata, asas-asas yang wajib ditaati dalam suatu perjanjian dapat dijumpai pada Pasal 1338 ayat (1), (2), dan ayat (3) meliputi :

1). Asas kebebasan berkontrak.

${ }^{2}$ Azhary, 1995, Negara Hukum Indonesia (Analisis Yuridis Normatif Tentang Unsurunsurnya), UI Pres Cet Pertama, Jakarta, hal. 33.

${ }^{3}$ Sudargo Gautama, 1973, Pengertian Tentang Negara Hukum, Alumni, Bandung, hal. 13.

${ }^{4}$ O. Notohamidjojo, 1970, Makna Negara

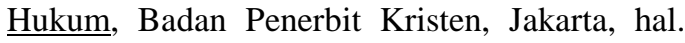
36.
Asas ini bermakna setiap orang bebas membuat perjanjian dengan siapapun, apapun isinya, apapun bentuknya sejauh tidak melanggar undang-undang, ketertiban umum dan kesusilaan (Pasal 1337 dan 1338 KUHPerdata). Asas ini menyebabkan hukum perjanjian bersistem terbuka. Adapun ruang lingkup asas kebebasan berkontrak menurut hukum perjanjian di Indonesia meliputi hal-hal sebagai berikut :

a. Kebebasan untuk membuat atau tidak membuat perjanjian.

b. Kebebasan untuk memilih dengan siapa ingin membuat perjanjian.

c. Kebebasan untuk menentukan atau memilih causa dari perjanjian yang akan dibuat.

d. Kebebasan untuk menentukan objek perjanjian.

e. Kebebasan untuk menentukan bentuk suatu perjanjian.

f. Kebebasan untuk menerima atau menyimpangi ketentuan perundang-undangan yang bersifat opsional. ${ }^{5}$

2). Asas itikad baik

Menurut Pasal 1338 KUHPerdata, setiap perjanjian harus dilaksanakan dengan itikad baik. Klasifikasi mengenai itikad baik dapat dibedakan atas 2 (dua) hal, yakni :

a. Bersifat obyektif, artinya mengindahkan kepatutan dan kesusilaan. Standar yang digunakan dalam iktikad baik obyektif adalah standar yang mengacu pada suatu norma obyektif.

b. Bersifat subyektif, artinya ditentukan sikap batin seseorang. Itikad baik subyektif dikaitkan dengan hukum benda.

${ }^{5}$ Frans Satriyo Wicaksono, 2008, Panduan Lengkap Membuat Surat-Surat Kontrak, Visimedia, Jakarta, hal. 3. 


\section{3). Asas Pacta Sunt Servanda}

Menurut ketentuan dari Pasal 1338 ayat (1) KUHPerdata menyatakan bahwa "Semua perjanjian yang yang dibuat sesuai dengan undang-undang yang berlaku sebagai undang-undang bagi mereka yang membuatnya." Asas ini menunjukkan kewajiban setiap pihak untuk menghormati sesuatu yang telah disepakatinya.

4). Asas konsensualisme

Asas ini dapat ditemukan dalam Pasal 1320 dan Pasal 1338

KUHPerdata. Dalam Pasal 1320

KUHPerdata penyebutannya secara tegas sedangkan dalam Pasal 1338 KUHPerdata ditemukan dalam istilah “semua". Kata-kata semua menunjukkan bahwa setiap orang diberi kesempatan untuk menyatakan keinginannya, yang dirasanya baik untuk menciptakan perjanjian. Asas ini sangat erat hubungannya dengan asas kebebasan mengadakan perjanjian. ${ }^{6}$

5). Asas kepribadian (personalitas).

Seorang tidak dapat mengadakan perjanjian kecuali untuk dirinya sendiri. Pengecualiannya terdapat dalam Pasal 1317 KUHPerdata tentang janji untuk pihak ketiga yang menegaskan bahwa "Dapat pula perjanjian diadakan untuk kepentingan pihak ketiga, bila suatu perjanjian yang dibuat untuk diri sendiri, atau suatu pemberian kepada orang lain mengandung suatu syarat macam itu". 7

${ }^{6}$ Mariam Darus Badrulzaman, 2001, Kompilasi Hukum Perikatan, PT. Cutra Aditya Bakti, Bandung, hal. 87.

${ }^{7}$ Handri Raharjo, 2009, Hukum Perjanjian Di Indonesia, Pustaka Yustisia, Yogyakarta, hal. 46. c). Teori Perjanjian

Perjanjian dalam KUHPerdata di atur dalam buku Ketiga tentang Perikatan, yaitu Pasal 1313 yang menentukan bahwa: "Perjanjian adalah suatu perbuatan hukum dengan mana satu orang atau lebih mengikatkan dirinya terhadap satu orang atau lebih". Apabila antara dua orang atau lebih tercapai suatu persesuaian kehendak untuk mengadakan suatu ikatan, maka terjadilah antara mereka suatu persetujuan. Sementara itu, Pasal 1121 KUHPerdata menentukan bahwa: "Tiada sepakat yang sah apabila sepakat itu diberikan karena kekhilafan atau diperolehnya dengan paksaan atau penipuan". Secara doktrinal, R. Subekti mengatakan bahwa: "suatu perjanjian adalah suatu peristiwa dimana seseorang berjanji kepada seorang yang lain atau dimana dua orang itu saling berjanji untuk melaksanakan suatu hal". ${ }^{8}$ Selanjutnya O.W Holmes berpendapat bahwa: "The duty on keep contract in common law means a prediction that you must pay damages if you do not keep it, if you commit a tort, you are liable to pay compesatory". 9

Menurut Pasal 1320 KUHPerdata, untuk sahnya suatu persetujuan diwajibkan memenuhi 4 (empat) syarat, yakni sepakat mereka yang mengikatkan dirinya, cakap untuk membuat suatu perikatan, adanya suatu hal tertentu, dan didasari atas suatu

${ }^{8}$ R. Soebekti, 2001, $\underline{\text { Hukum }}$ Perjanjian, PT. Intermasa, Jakarta, hal. 45.

${ }^{9}$ M.P Golding, 2001, The Nature of Law Readings in Legal Philosophy, Columbia University, Random House, New York, hal. 180. 
sebab yang halal. Syarat pertama dan kedua disebut syarat subyektif karena kedua syarat tersebut harus dipenuhi oleh subyek hukum, sedangkan syarat ketiga dan keempat disebut syarat obyektif karena kedua syarat ini harus dipenuhi oleh obyek perjanjian. Tidak dipenuhinya syarat subyektif akan mengakibatkan suatu perjanjian menjadi dapat dibatalkan. Sedangkan tidak dipenuhinya syarat obyektif akan mengakibatkan perjanjian tersebut menjadi batal demi hukum, sehingga "sejak semula dianggap tidak pernah dilahirkan suatu perjanjian dan tidak pernah ada suatu perikatan". ${ }^{10}$

\section{d). Teori Kepastian Hukum}

Tujuan hukum menurut Apeldoorn adalah untuk mengatur pergaulan hidup secara damai. ${ }^{11}$ Sementara itu, menurut Gustav Radbruch yang mengembangkan

Geldingstheorie mengemukakan bahwa untuk berlakunya hukum secara sempurna harus memenuhi tiga nilai dasar, meliputi ${ }^{12}$ :

1. Juridical doctrine, nilai kepastian hukum, dimana kekuatan mengikatnya didasarkan pada aturan hukum yang lebih tinggi.

2. Sociological doctrine, nilai sosiologis, artinya aturan hukum mengikat karena diakui dan diterima dalam masyarakat (teori pengakuan) atau dapat dipaksakan sekalipun masyarakat menolaknya (teori paksaan).

3. Philosophical doctrine, nilai filosofis, artinya aturan hukum mengikat karena sesuai dengan cita hukum, keadilan sebagai nilai positif yang tertinggi.

Dengan demikian, agar hukum dapat berlaku dengan sempurna dan menjamin kepastian hukum, maka

${ }^{10}$ Komariah, 2002, Hukum Perdata, Universitas Muhammadiah, Malang, hal. 175-177.

${ }^{11}$ L. J. Van Apeldoorn, 2000, Pengantar Ilmu Hukum, Pradnya Paramita, Jakarta, hal. 10.

${ }^{12}$ Satjipto Rahardjo, 1996, Ilmu Hukum, PT. Citra Aditya Bakti, Bandung, hal. 19. perlu memenuhi tiga nilai dasar tersebut. Dengan kata lain, adanya unsur kepastian hukum dalam pembuatan Akta PPAT akan dapat memberikan jaminan perlindungan hukum bagi setiap orang maupun aparat pemerintah, mengingat kepastian hukum itu sebagai syarat untuk memberikan jaminan perlindungan bagi yang berhak.

\subsection{Metode Penelitian}

\subsubsection{Jenis Penelitian}

$\begin{array}{ccc}\text { Penelitian } & \text { ini } & \text { dapat } \\ \text { dikualifikasikan } & \text { kedalam } & \text { jenis }\end{array}$ penelitian hukum normatif. Penelitian ini berangkat dari kekosongan norma hukum pada PP No. 24 Tahun 1997 terkait keberadaan kuasa menjual dalam peralihan dan pendaftaran hak atas tanah.

\subsubsection{Jenis Pendekatan}

Pendekatan yang digunakan dalam menjawab persoalan yang telah dirumuskan adalah dengan menggunakan pendekatan undangundang (statue approach), pendekatan konseptual (conseptual approach). Namun demikian, tidak menutup kemungkinan juga akan dipergunakan pendekatan kasus (case approach).

\subsubsection{Sumber Bahan Hukum}

Bahan hukum penelitian ini diperoleh dari bahan hukum primer, sekunder, dan tertier. Bahan hukum primernya seperti UUJN, KUHPerdata, PP No. 24 Tahun 1997, bahan hukum sekundernya berupa buku-buku, disertasi dan hasil penelitian lain, serta bahan hukum tertiernya antara lain kamus hukum dan ensiklopedia. 


\subsubsection{Teknik Pengumpulan Bahan} Hukum

Dalam penelitian ini, teknik pengumpulan bahan hukum yang dilakukan dengan metode bola salju. Metoda bola salju adalah metode dimana bahan hukum dikumpulkan melalui beberapa literatur kemudian dari beberapa literatur tersebut diambil sejumlah sumber yang mendukung literatur tersebut.

1.6.5. Teknik Pengolahan Dan Analisis Bahan Hukum

Analisis dalam penelitian merupakan bagian yang sangat penting karena dengan analisis inilah bahan hukum yang ada akan nampak manfaatnya dalam memecahkan masalah. ${ }^{13}$ Dengan demikian, bahan hukum yang telah dikumpulkan dan disistematisir kemudian ditafsirkan dan dianalisis yang dilakukan dengan menggambarkan apa yang menjadi masalah (deskripsi), menjelaskan masalah (eksplanasi), mengkaji permasalahan dari bahan-bahan hukum yang terkait (evaluasi) dan memberikan argumentasi dari hasil evaluasi tersebut.

II. HASIL DAN PEMBAHASAN

\subsection{Kuasa Menjual dan Surat Keterangan Pembayaran Lunas dalam jual beli tanah}

Menurut ketentuan Pasal 1792 KUHPerdata menentukan bahwa, pemberian kuasa merupakan suatu perjanjian dengan mana seorang memberikan kekuasaan kepada seorang lain, yang menerimanya, untuk atas namanya, menyelenggarakan suatu

${ }^{13}$ P.Joko Subagyo, 1999, Metode Penelitian Dalam Teori dan Praktek, Cet. III, Rineka Cipta, Jakarta, hal. 104. urusan. Kuasa dapat diberikan dan diterima dalam suatu akta umum, dalam suatu tulisan dibawah tangan, bahkan dalam sepucuk surat ataupun dengan lisan. Mengenai jenis-jenis pemberian kuasa dapat dilakukan dengan dua cara yaitu dengan cara khusus dan cara umum. Pemberian kuasa yang diberikan secara khusus, pada hakikatnya hanya mengenai satu kepentingan tertentu atau lebih, sedangkan pemberian kuasa secara umum akan meliputi segala kepentingan si pemberi kuasa (Pasal 1795 KUHPerdata). Sementara itu, pemberian kuasa Notariil merupakan pemberian kuasa dalam bentuk tertulis yang dibuat oleh pejabat Notaris.

Sebelum membuat akta kuasa, terlebih dahulu pejabat Notaris akan menanyakan untuk kepentingan apa akta kuasa tersebut dibuat. Notaris juga meminta data identitas masingmasing pihak yaitu Kartu Tanda Penduduk (KTP) pemberi dan penerima kuasa, Kartu Tanda Penduduk (KTP) suami atau istri pemberi kuasa Kartu Keluarga (KK) pemberi kuasa, atau surat nikah permintaan dokumendokumen tersebut terkait dengan kepentingan legalitas dan persyaratan yang dituntut oleh peraturan perundang-undangan. Selain itu Notaris akan menanyakan syarat-syarat khusus apa yang dibuat oleh para pihak agar dapat dicantumkan didalam akta.

Mengenai dasar hukum pemberian kuasa dapat dijumpai pada Pasal 1792 KUHPerdata yang menentukan bahwa, "pemberian kuasa adalah suatu perjanjian dengan mana seorang lain memberikan kekuasaan kepada seorang 
lain, yang menerimanya untuk atas namanya, menyelenggarakan suatu urusan”. Pemberian kuasa (lastgeving) juga diatur dalam buku III Bab XVI mulai dari Pasal 17921819KUHPerdata. Adanya surat kuasa menjual dalam jual beli tanah telah menjadi dasar beralihnya uang dan tanah antara pembeli dengan penjual. Namun demikian, secara normatif adapun peralihan tersebut belum sah karena masih dibutuhkan prosedur dan persyaratan-persyaratan tertentu untuk sahnya peralihan hak atas tanah.

Jual beli hak milik atas tanah adalah perbuatan hukum untuk memindahkan hak atas tanah kepada pihak lain. Pemindahan hak dilakukan apabila status hukum pihak yang akan menguasai tanah tersebut memenuhi persyaratan sebagai pemegang hak atas tanah tersebut bersedia untuk memindahkan haknya. Dalam hal ini, penjual dan pembeli datang ke kantor PPAT untuk membuat akta mengenai tanah yang dijual. Dengan dibuatnya akta jual beli tanah oleh PPAT maka pada saat itu juga hak beralih dari penjual kepada pembeli dan tanpa akta PPAT jual beli tersebut tidak dapat didaftarkan ke Kantor Pertanahan dengan memenuhi syarat-syarat yang dibutuhkan, seperti pembayaran lunas atas tanah yang dibeli dan apakah harga tanah sesuai dengan akta yang telah diserahkan oleh pembeli kepada penjual, dan apakah penjual telah menerima harga tanah tersebut dari pembeli. Pertanyaan tersebut perlu ditanyakan karena dalam akta ditulis bahwa uang pembelian sudah dibayar lunas dan diterima oleh penjual, sehingga akta itu juga berlaku sebagai tanda terima yang sah.
Mengenai pembayaran dalam jual beli tanah ini dalam prakteknya akan dilakukan dalam dua tahap yang berbeda. Pertama, pembayaran telah dimulai sebelum jual beli dilakukan dihadapan PPAT, sedangkan yang kedua pembayaran baru dimulai setelah penandatanganan perjanjian jual beli. Namun demikian, ada juga yang telah dibayar lunas sebelum penandatanganan perjanjian jual beli, bahkan ada pula yang membayar tersebut harus dibuatkan kwitansi/tanda terima. Oleh karena itu, kwitansi pembayaran yang dimaksudkan ini sengaja dibuat untuk dijadikan suatu bukti bahwa telah terjadi penerimaan sejumlah uang sesuai dengan yang tertera pada kwitansi tersebut. Oleh karena itu, kwitansi yang ditandatangani hanya berlaku antara pihak pembayar dan penerima saja. ${ }^{14}$ Setelah menerima dan memeriksa surat-surat yang diperlukan, maka Notaris/PPAT akan membuat akta jual beli tanah yang ditandatangani oleh para pihak atau kuasanya, dua orang saksi dan Notaris/PPAT itu sendiri.

\subsection{Kedudukan Akta Jual Beli Balik Nama dalam Jual Beli Tanah}

Akta jual beli pada hakikatnya mempunyai tiga unsur pokok yakni unsur Essensialia, unsur Naturalia, dan unsur Aksidentalia. Sementara itu, perbuatan hukum jual beli merupakan bagian dari perjanjian dan perikatan. Pasal 1313 KUHPerdata menentukan bahwa, "Suatu persetujuan adalah suatu perbuatan dengan mana 1 (satu) orang atau lebih mengikatkan dirinya terhadap 1 (satu) orang lain atau lebih". Jual beli merupakan suatu bentuk perjanjian yang melahirkan kewajiban atau perikatan untuk memberikan sesuatu, yang dalam hal ini terwujud dalam bentuk penyerahan kebendaan yang dijual oleh penjual dan penyerahan uang

${ }^{14}$ Harun Al Kashid, 1987, Sekilas Tentang Jual Beli Tanah (Berikut Peraturan Peraturanperaturannya), Ghalia Indonesia, Jakarta, hal.62 
oleh pembeli kepada penjual. ${ }^{15}$ Pada pihak lain, perjanjian jual beli dapat dikualifikasikan sebagai suatu perjanjian obligatoir dengan tidak mengurangi baik unsur-unsur perjanjian, syarat sahnya perjanjian maupun asas-asas hukum perjanjian sebagaimana telah diuraikan diatas. ${ }^{16}$

\subsection{Fungsi Akta Jual Beli Balik Nama dalam}

\section{Jual Beli Tanah}

Menurut Pasal 1870 dan 1871 KUHPerdata maka akta otentik bagi para pihak dan ahli warisnya serta mereka yang memperoleh hak daripadanya, merupakan bukti sempurna, tentang apa yang termuat didalamnya dan bahkan tentang yang terdapat dalam akta sebagai penuturan belaka, yang terakhir ini hanya sepanjang yang dituturkan itu ada hubungannya langsung dengan pokok akta. Bilamana yang dituturkan dalam akta tersebut tidak ada hubungan langsung dengan pkok akta, menurut Pasal 1871 KUHPerdata hal itu hanya akan berlaku sebagai permulaan bukti tertulis. Selanjutnya menurut Pasal 1872 KUHPerdata apabila akta otentik yang bagaimanapun sifatnya diduga palsu, maka pelaksanaannya dapat ditangguhkan.

Mengenai fungsi Akta jual beli balik nama atau Akta PPAT jual beli menurut Mahkamah Agung dalam Putusannya no. 1363/K/Sip/1997 berpendapat bahwa Pasal 19 PP No.10 tahun 1961 secara jelas menentukan bahwa akta PPAT hanyalah suatu alat bukti dan tidak menyebut bahwa akta itu adalah syarat mutlak tentang sah tidaknya suatu jual beli tanah. Selanjutnya dalan Yuridisprudensi MA. No. 123/K/Sip/1997, pendaftaran tanah hanyalah perbuatan hukum administrasi belaka, artinya bahwa pendaftaran bukan merupakan syarat bagi sahnya atau menentukan berpindahnya hak atas tanah dalam

${ }^{15}$ Gunawan Widjaja dan Kartini Muljadi Widjaja, 2004, Jual Beli, PT Raja Grafindo Persada, Jakarta, hal. 7.

${ }^{16}$ Herlien Budiono, 2007, Kumpulan Tulisan Hukum Perdata dibidang Kenotariatan, PT. Citra Aditya Bakti, Bandung, hal.269-270. jual beli. Dengan demikian, Akta PPAT berfungsi sebagai alat pembuktian mengenai benar sudah dilakukannya jual beli. Orang yang akan melakukan jual beli tanpa dibuktikan dengan akta PPAT tidak akan memperoleh sertipikat, meskipun jual belinya sah menurut hukum. ${ }^{17}$ Dalam hal ini, keberadaan Akta jual beli hak atas tanah menjadi sangat penting yang berfungsi untuk terjadinya pemindahan hak atas tanah dan terjadinya kepemilikan hak atas tanah, agar transaksi jual beli bisa dipertanggungjawabkan.

\subsection{Faktor-faktor Yang Melatar belakangi Lahirnya Surat Keterangan Notaris Tentang Pembayaran Lunas dalam Jual Beli Tanah}

Pada ketentuan Perikatan Jual Beli (AJB) dicantumkan kapan AJB akan dilaksanakan beserta persyaratan yang dibutuhkan. Didalam PJB lunas juga dicantumkan mengenai kuasa dari penjual kepada pembeli untuk menandatangani Akta Jual Beli (AJB), sehingga penandatanganan AJB nantinya tidak memerlukan lagi kehadiran penjual secara fisik. Sementara itu, dijumpai beberapa faktor yang menyebabkan lahirnya Surat Keterangan Notaris dalam pembayaran lunas pada peralihan jual beli balik nama bidang tanah yakni :

1. Untuk mengikat para pihak antara penjual dan pembeli dalam hal peralihan jual beli balik nama.

2. Memberikan jaminan kepada Pembeli dalam pembayaran lunas.

3. Untuk mempermudah tugas Notaris dalam memproses peralihan hak atas tanah.

4. Menerangkan keadaan obyek yang telah dibayar lunas

5. Secara faktual obyek sudah beralih secara Hukum, namun secara Normatif belum dikatakan beralih.

${ }^{17}$ Adrian Sutedi, 2009, Peralihan Hak Atas Tanah Dan Pendaftarannya, Sinar Grafika, Cet. III, Jakarta. hal. 79. 
Dengan menggunakan surat keterangan Notaris yang diikuti surat kuasa menjual dalam peralihan hak suatu bidang tanah yang dibuat oleh dan/atau dihadapan Notaris/PPAT sebagai perjanjian pendahuluan untuk dasar dibuatnya akta jual beli balik nama secara faktual tanah bersangkutan sudah beralih, akan tetapi secara normatif belum. Hal ini tidak terlepas dari kekuatan pembuktian surat keterangan Notaris masih diragukan tidak seperti halnya penggunaan perjanjian perikatan jual beli (PPJB) yang didalamnya menerangkan dan menyatakan janji-janji yang harus dipenuhi terlebih dahulu oleh salah satu pihak atau para pihak sebelum dapat dilakukannnya perjanjian pokok yang merupakan tujuan akhir dari para pihak. Persyaratan tersebut tentunya dapat bersifat macam-macam. Sebagaimana telah kita ketahui bahwa untuk terjadinya jual beli hak atas tanah dihadapan PPAT harus telah dilunasi harga jual belinya. Mungkin pula adanya keadaan dimana penjual yang sertipikat hak atas tanahnya sedang dalam penyelesaian balik namanya pada Kantor Badan Pertanahan Nasional tetapi penjual bermaksud untuk menjual hak atas tanah tersebut. Untuk mengatasi hal tersebut maka dibuatlah suatu perikatan jual beli sebagai suatu perjanjian pendahuluan untuk sementara menantikan dipenuhinya syarat untuk perjanjian pokoknya yakni jual beli di hadapan PPAT yang berwenang untuk membuatnya. Dengan demikian tidak diragukan lagi kekuatan pembuktian daripada perjanjian pendahuluan tersebut, meskipun tidak seperti kekuatan pembuktian surat keterangan sebagai pengganti PPJB yang dijumpai dibuat juga oleh beberapa PPAT.

\subsection{Fungsi Surat Keterangan Notaris Tentang Pembayaran Lunas Dalam Peralihan Hak Atas Tanah}

Sahnya jual beli tanah dengan adanya akta jual beli dihadapan PPAT berakibat hukum dapat didaftarkan peralihan hak atas tanah tersebut ke Badan Pertanahan. Sedangkan apabila jual beli tanah tidak dilakukan dihadapan PPAT, maka Keputusan Mahkamah Agung tanggal 1 April 1976 No. 126 K/Sip/1976 menetapkan bahwa untuk sahnya jual beli tanah, tidak mutlak harus dengan akta yang dibuat oleh dan dihadapan PPAT, akta pejabat ini hanyalah suatu alat bukti.

Mengenai fungsi akta PPAT dalam jual beli, Mahkamah Agung dalam Putusannya No. 1362/K/Sip/1997 berpendapat bahwa Pasal 19 PP No. 10 Tahun 1961 secara jelas menentukan bahwa akta PPAT hanyalah suatu alat bukti dan tidak menyebut bahwa akta itu adalah syarat mutlak tentang sah tidaknya suatu jual beli tanah. Menurut Boedi Harsono, akta PPAT berfungsi sebagai alat pembuktian mengenai benar sudah dilakukannya jual beli. Jual beli tersebut masih dapat dibuktikan dengan alat pembuktian yang lain, akan tetapi dalam sistem pendaftaran tanah menurut PP No. 24 tahun 1997, pendaftaran jual beli itu hanya dapat dilakukan dengan akta PPAT sebagai buktinya. Orang yang melakukan jual beli tanpa dibuktikan dengan akta PPAT tidak akan dapat memperoleh sertifikat, biarpun jual belinya sah menurut hukum. ${ }^{18}$

${ }^{18}$ Adrian Sutedi, Ibid., hal 79 


\subsection{Kedudukan Surat Kuasa Menjual Yang Didasarkan Surat Keterangan Notaris Tentang Pembayaran Lunas}

Surat kuasa menjual pada dasarnya berkedudukan sebagai perjanjian bantuan atau akta di bawah tangan yang berfungsi dan mempunyai tujuan untuk melindungi posisi pembeli dan juga dapat mempermudah pekerjaan Notaris bila mana pada saat penjual tidak dapat hadir kedua kalinya atau berhalangan untuk menanda tangani akta jual beli maka penjual dapat memberikan kuasa menjual kepada pembeli, kuasa menjual pihak dalam suatu perjanjian tentang harga dan barang/benda (tanah dan/atau bangunan) sebagai obyek perjanjian jual beli. Sebab dengan sepakatnya para pihak tentang obyek perjanjian serta telah dibayar lunas harga tanah dan/atau bangunan oleh pembeli dan diterima oleh penjual sebaliknya penjual menyerahkan tanah dan/atau bangunannya kepada dan telah diterima oleh pembeli, maka unsur-unsur jual beli telah terpenuhi dan oleh Notaris cukup dijadikan alasan dibuatnya surat keterangan Notaris sebagai pengganti PPJB dan kuasa menjual.

Dalam sebuah surat keterangan Notaris akan dapat dijumpai harga tanah berikut bangunannya yang telah dibayar lunas (terjadi pelunasan) oleh pembeli kepada penjual/pemilik tanah. Secara yuridis berarti akta tersebut telah memenuhi syarat sebagai dasar peralihan hak atas tanahnya, yang diikuti dengan akta kuasa menjual. Adanya kuasa menjual dari pemilik tanah selaku penjual kepada pembeli, maka segala kepentingan hukumnya dapat dilaksanakan. Dengan kata lain, dengan kuasa menjual maka pembeli dikemudian hari dapat menjual kepada pihak lain dengan tanpa memerlukan bantuan hukum penjual atau dalam hal ini digunakan untuk menjual kepada dirinya pembeli sendiri guna kepentingan peralihan hak atas tanah dan bangunan tersebut.
Adanya akta kuasa menjual maka seorang penerima kuasa dapat menjalankan kekuasaan yang diberikan oleh pemberi kuasa, Namun demikain, ia tidak boleh bertindak melampaui batas yang diberikan kepadanya oleh pemberi kuasa. Oleh karena tindakan dan pemegang kuasa itu sebenarnya mewakili, demikian untuk dan atas nama pemberi kuasa, maka pemberi kuasa dapat dalam arti kata berhak untuk menggugat secara langsung dan menuntut orang ketiga dengan siapa pemegang kuasa telah bertindak dalam kedudukannya, agar perjanjian yang bersangkutan dipenuhinya.

\subsection{Fungsi Surat Kuasa Menjual Dalam \\ Peralihan Hak Atas Tanah}

Akta jual beli yang dibuat dihadapan PPAT sesuai dengan peraturan perundang-undangan yang berlaku merupakan akta otentik yang dibuat dengan itikad baik dan terang karena dilakukan dihadapan pejabat yang berwenang dan merupakan tanda penerimaan yang sah (kuitansi) dalam jual beli dengan tunai tersebut. Oleh karenanya sejak ditandatangani akta jual beli ini maka beralihlah hak atas tanah dari pihak penjual kepada pihak pembeli.

Dalam pasal 37 PP No. 24 Tahun 1997 menyebutkan bahwa peralihan hak atas tanah melalui jual beli hanya dapat didaftarkan jika dibuktikan dengan akta yang dibuat PPAT yang berwenang menurut ketentuan perundang-undangan. Pendaftaran di sini bukan merupakan syarat terjadinya pemindahan hak karena pemindahan hak telah terjadi setelah dilakukan jual belinya di hadapan PPAT. Dengan demikian jual beli tanah telah sah dan selesai dengan pembuatan akta PPAT dan akta PPAT tersebut merupakan 
bukti bahwa telah terjadi jual beli, yakni bahwa pembeli telah menjadi pemiliknya dan pendaftaran peralihan hak di Kantor Agraria bukanlah merupakan syarat bagi sahnya transaksi jual beli tanah dan pendaftaran disini hanya berfungsi untuk memperkuat pembuktiannya terhadap pihak ketiga atau umum. Memperkuat pembuktian maksudnya memperkuat pembuktian mengenai terjadinya jual beli dengan mencatat pada buku tanah dan sertifikat hak tanah yang bersangkutan, sedangkan memperluas pembuktian dimaksudkan untuk memenuhi asas publisitas karena dengan dilakukannya pendaftaran jual belinya maka diketahui oleh pihak ketiga yang berkepentingan.

Dalam praktek serta kenyataan dimasyarakat tidak jarang terjadi suatu keadaan dimana si pemilik hak atas tanah (penjual) yang sertipikat tanah haknya belum terbit atau belum terdaftar atas namanya yang disebabkan karena :

a. Masih dalam proses peralihan Hak.

b. Masih ada proses balik nama menjadi ke atas namanya yang timbul sehubungan dengan adanya pemindahan/peralihan hak, atau

c. Masih terikat sebagai jaminan atas suatu hutang.

Akan tetapi yang bersangkutan bermaksud untuk menjual tanah hak tersebut dan ada pembeli yang mungkin berkeinginan untuk membeli tanah tersebut dari penjual meskipun pembeli mengetahui bahwa sertipikat tanah yang bersangkutan masih terkendala sebagaimana yang disebutkan diatas sehingga tidak memungkinkan dibuat dan ditanda tanganinya akta jual beli dihadapan PPAT. Guna mengatasi hal tersebut maka disinilah akan dibuatkan suatu surat keterangan Notaris dan berfungsinya kuasa menjual sebagai suatu perjanjian pendahuluan untuk sementara, menantikan dipenuhinya syarat untuk perjanjian pokok yaitu pembuatan akta jual beli dihadapan Pejabat Pembuat Akta Tanah (PPAT) yang berwenang untuk membuatnya.

Banyak orang yang datang untuk membuat perjanjian perikatan jual beli namun dalam hal ini perjanjian perikatan jual beli (PPJB) diganti dengan Surat Keterangan Notaris yang diikuti kuasa menjual sebelum terjadinya jual beli itu dikarenakan dikemudian harinya pihak penjual dikhawatirkan tidak dapat datang kembali untuk membuat jual belinya sendiri dihadapan Pejabat Pembuat Akta Tanah (PPAT). Guna mengatasi hal tersebut, maka pembeli diberi kuasa untuk dapat melakukan jual belinya sendiri baik mewakili penjual maupun dirinya sendiri selaku pembeli untuk dapat mewakili secara umum hak-hak kepengurusan atas tanah tersebut selama belum dilakukan jual beli dihadapan pejabat yang dimaksud. Hal mana perlu diingat bahwa adanya kemungkinan calon penjual tidak berada ditempat untuk melakukan tindakan hukum yang masih merupakan kewajibannya tersebut.

Apabila Perjanjian pengikatan jual beli atau dalam hal ini diganti dengan surat keterangan yang dibuat oleh Notaris, maka Notaris seyogyanya telah mengantisipasi keadaan itu dengan mencantumkan kuasa-kuasa yang dimaksud untuk itu agar calon pembeli tidak dirugikan haknya, mengingat telah dipenuhi semua persyaratan untuk jual belinya dihadapan Pejabat yang berwenang. Kuasakuasa demikian diberikan dengan ketentuan bahwa kuasa mana tidak dapat ditarik kembali dan kuasa mana baru berlaku apabila syarat tangguh atas jual belinya tidak dipenuhi suatu perjanjian pemberi kuasapada umumnya merupakan suatu perjanjian sepihak, dimana kewajiban untuk melaksanakan prestasi hanya 
terdapat pada satu pihak saja yaitu pada penerima kuasa.

\section{PENUTUP}

\subsection{Kesimpulan}

Berdasarkan uraian pembahasan yang telah disampaikan pada tesis ini, maka kesimpulan terhadap terhadap kedua permasalahan yang dikaji adalah sebagai berikut :

1. Bahwa kedudukan surat keterangan Notaris dengan kuasa menjual sebagai dasar dibuatnya akta jual beli balik nama yang dibuat oleh dan/atau dihadapan PPAT berfungsi sebagai perjanjian bantuan dan akta di bawah tangan dengan tujuan untuk melindungi posisi pembeli dan juga memperlancar pekerjaan Notaris/PPAT dalam membuat akta jual beli beserta pendaftaran peralihan hak atas tanah yang menjadi obyek jual beli. Berdasarkan Pasal 1875 KUHPerdata keterangan notaris dengan kuasa menjual yang dipandang sebagai akta di bawah tangan tersebut dapat mengikat dan mempunyai kekuatan sebagaimana akta otentik apabila bahwa keberadaannya maupun tanda tangannya tidak disangkal olah masing-masing pihak. Selanjutnya kuasa menjual juga memberikan hak kepada penerima kuasa (pembeli) dikemudian hari untuk menjual kepada pihak lain obyek jual beli bersangkutan tanpa bantuan hukum pihak penjual atau dalam hal digunakan untuk menjual kepada dirinya (pembeli sendiri) guna kepentingan peralihan hak atas tanah dan bangunan tersebut.
2. Bahwa Kuasa menjual yang mengikuti surat keterangan Notaris bukan sebagai kuasa mutlak yang bertentangan dengan Instruksi Menteri Dalam Negeri No. 14 Tahun 1982 sehingga akta jual beli balik namanya tidak dapat dijadikan alat pendaftaran peralihan hak atas tanahnya pada Kantor Pertanahan. Kuasa menjual yang mengikuti surat keterangan Notaris merupakan suatu perbuatan hukum ikutan dari perjanjian pendahuluan (perjanjian bantuan) yang berfungsi dan mempunyai tujuan untuk mempersiapkan, menegaskan, memperkuat, mengatur, mengubah atau menyelesaikan suatu hubungan hukum jual belinya dihadapan notaris/PPAT sampai pada pendaftaran peralihan hak atas tanah yang menjadi obyek jual beli.

\subsection{Saran-saran}

Sehubungan dengan hasil pembahasan atas kedua permasalahan pada tesis ini, adapun beberapa saran yang dapat disampikan adalah sebagai berikut :

a. Kepada Pihak Pemerintah c.q. Badan Pertanahan Nasional perlu ditegaskan terkait kepastian keberadaan surat atau akta kuasa menjual dalam pembuatan Akta Jual Beli yang dijadikan dasar pendaftaran peralihan hak atas tanah karena secara faktual perbuatan hukum tersebut sering terjadi di masyarakat namun secara normatif belum diatur secara pasti terkait sah tidaknya pembuatan kuasa menjual tersebut; 
b. Kepada Pihak Notaris/PPAT

sebaiknya surat keterangan lunas

pura-pura dihindari pembuatannya

karena dapat menimbulkan

persoalan hukum dikemudian hari

dalam hal terjadinya wanprestasi

salah satu pihak terkait perjanjian

pengikatan jual beli atau akta

pengikatan jual beli yang

dibuatnya;

c. Kepada pihak masyarakat yang

melakukan jual beli tanah sebaiknya mengikuti ketentuan peraturan perundang-undangan yang berlaku untuk menghindari terjadinya konflik di kemudian hari atas pengingkaran atau perbuatan melampaui hak yang timbul oleh para pihak baik terkait dengan keberadaan kuasa menjual maupun surat keterangan lunas dibayar yang dibuat pura-pura atas obyek jual beli.

\section{DAFTAR PUSTAKA}

Apeldoorn, L. J. Van, 2000, Pengantar Ilmu Hukum, Pradnya Paramita, Jakarta.

Azhary, 1995, Negara Hukum Indonesia (Analisis Yuridis Normatif Tentang Unsur-unsurnya), UI Pres Cet Pertama, Jakarta.

Badrulzaman, Mariam Darus, 2001, Kompilasi Hukum Perikatan, PT. Citra Aditya Bakti, Bandung.

Gautama, Sudargo, 1973, Pengertian Tentang Negara Hukum, Alumni, Bandung.

Golding, M.P., 2001, The Nature of Law Readings in Legal Philosophy, Columbia University, Random House, New York.

Hadjon, Philipus M., 2007, Perlindungan Hukum Bagi Rakyat di Indonesia, Sebuah Studi tentang Prinsipprinsipnya, Penanganannya oleh Pengadilan dalam Lingkungan Peradilan Umum dan Pembentukan Peradilan Administrasi, Peradaban, Surabaya.

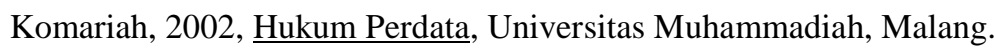

Notohamidjojo, O., 1970, Makna Negara Hukum, Badan Penerbit Kristen, Jakarta.

Rahardjo, Satjipto, 1996, Ilmu Hukum, PT. Citra Aditya Bakti, Bandung.

Raharjo, Handri, 2009, Hukum Perjanjian Di Indonesia, Pustaka Yustisia, Yogyakarta.

Rashid, Harun Al, 1987, Sekilas Tentang Jual Beli Tanah (Berikut Peraturan Peraturan-peraturannya), Ghalia Indonesia, Jakarta.

Soebekti, R., 2001, Hukum Perjanjian, PT. Intermasa, Jakarta.

Subagyo, P. Joko, 1999, Metode Penelitian Dalam Teori dan Praktek, Cet. III, Rineka Cipta, Jakarta.

Sutedi, Adrian, 2009, Peralihan Hak Atas Tanah Dan Pendaftarannya, Sinar Grafika, Cet. III, Jakarta.

Wicaksono, Frans Satriyo, 2008, Panduan Lengkap Membuat Surat-Surat Kontrak, Visimedia, Jakarta. 